\title{
Mastering Compound Word for Teachers and Learners of English
}

\author{
Jimmi $^{1}$, Juniato Sidauruk ${ }^{2}$ \\ ${ }^{1,2}$ Universitas Bina Sarana Informatika \\ e-mail: jimmi.jmm@ bsi.ac.id ${ }^{1}$,junianto.jnd@ @si.ac.id ${ }^{2}$;juniato276@ gmail.com²

\begin{tabular}{ccc}
\hline Diterima & Direvisi & Disetujui \\
$21-01-2020$ & $19-02-2020$ & $26-02-2020$ \\
\hline
\end{tabular}

\begin{abstract}
This study focuses on compound word and its need to be mastered by teachers and English learners. There are new words coming up almost every day. Most of them are by combining of two different words, blending and many other morphological phenomena. The formed new word is commonly known as wordformation. The discussion covers on word-formation specifically on the types of compound word and its meaning. A new word is formed from the same or different word classes. This word formation must be mastered by the English teachers and also the learners of English. The Semantic theoryis used just to study the meaning of the word not the sentence. This research uses descriptive qualitative method. The data were taken from The Time of the Oath Album By Helloween.The results show that there are three types compound words found. Compound Noun is the most dominant followed by Adjective and Verb. The Endocentric Compound is the most productive compound in meaning.
\end{abstract}

\section{Keywords: Compound Word, Word Formation, Teacher}

Abstrak -- Studi ini berfokus pada kata majemuk dan kebutuhannya untuk dikuasai oleh guru dan pelajar bahasa Inggris. Ada kata-kata baru yang muncul hampir setiap hari. Kebanyakan dari mereka adalah dengan menggabungkan dua kata yang berbeda, campuran dan banyak fenomena morfologis lainnya. Kata baru yang terbentuk umumnya dikenal sebagai pembentukan kata. Diskusi tersebut membahas tentang pembentukan kata khususnya pada jenis kata majemuk dan artinya. Kata baru dibentuk dari kelas kata yang sama atau berbeda. Pembentukan kata ini harus dikuasai oleh guru bahasa Inggris dan juga pelajar bahasa Inggris. Teori Semantik digunakan hanya untuk mempelajari makna kata, bukan kalimat. Penelitian ini menggunakan metode deskriptif kualitatif. Data diambil dari The Time of the Oath Album By Helloween. Hasilnya menunjukkan bahwa ada tiga jenis kata majemuk yang ditemukan. Kata Majemuk Kata Benda adalah yang paling dominan diikuti oleh Kata Sifat dan Kata Kerja. Kata majemuk endosentris adalah kata majemuk yang paling produktif dalam hal makna.

\section{Kata kunci: Kata Majemuk, Pembentukan Kata, Guru}

\section{INTRODUCTION}

Language is evolving everyday. Many new words, phrases and terminology have become the part of society. English as international language must cope up with such issues. People need a tool to put out their ideas, and language is the most effective tools. Bloch and Trager in (Ceylan, 2017) states that Language is a system of arbitrary vocal symbols by means of which a social group cooperates. By using language, people can develop their knowledge and know something. People -teachers and learners are users of language. Besides, people also use language to write, speak, and analyse, for example, writing a novel. People want the language to be flexible. They want words or phrases that can express a specific or broad meaning for communication. One of the evolution is compound word.
Compound word is very effective to enrich the vocabulary of a language. One may take one word and pair it to another and create a new meaning, whether it is a correlative or a whole new one. Lyrics are usually the birthplace of new word. Lyrics force the writers to narrate and describe the text in a unique way. Thus, create the space for writers to fill the compound word as part of the text.

Lyrics can be studied for an academic perspective. Lyrics may contain political, social, and economic themes as well as aesthetic elements and so can communicate culturally significant messages. These messages can be explicit, or implied through compound word. Studying compound word has its own interesting values. Teachers and learners of English are able to enrich their vocabulary and 
perhaps creating a new compound word to express their own ideas.

This study focuses on compound word and will not discuss any other morphological phenomena.The Semantic theory will only be used to study the meaning of the word not the sentence. The corpus is Helloween's Album The Time of the Oath Japanese version.

This is a linguistics research. Specifically it is a morphology study. Morphology is a linguisctic science that focuses on word. Morphology as one of the most important studies in linguistics is very important for teachers and learners of English. It studies about how the words are built up from the smallest pieces. Understanding the formation of those words is very useful for the learners since English is considered as the foreign language in Indonesia. The learners learn the words and try to know how to use and organize them. This process is a part of morphological process in English. Morphology is concerned with the study of how words is formed in language. Morphology is the study of the internal structures of word, how it is formed by the smaller pieces.

According to (Eunhee Lee, 2015), Morphology is a sub-discipline of linguistics that deals with systematic patterns of word formation rules and the internal constituent structure of words. Therefore, morphology deals with the internal constituent structure of words as well. A word itself has a meaning, but word can be grammatically simple and complex. Complex word is word that has internal structure that can be divided into smaller part, while the simple word is the smallest word only consisting of one single morpheme that has a meaning.

Bauer in (Rahadiyanti, 2017) states that morphology is the study which deals the internal structure of word forms. Bauer agrees that morphology is the field to study the word structure in word forms.

Haspelmath in (Yastanti, 2018) states that Morphology is the study of systematic covariation in the form and meaning of words. This means morphology does not end up in level of only one word. It studies the connection of one word to another through a systematical approach. A new word can be formed naturally because of the habits, environments and changing times. This study discussed about words that are created through the process of word formation, specifically compounding. This theory can be used as a strong bases to learn this research.
(Booij, 2012) states that compound word is wordformation that consist of two lexemes (base word). Booij does not state "word" because "word" might be modified by derivation or inflection while compound word is usually described as base words to differentiate compound word and word phrase. For example:

Deep Fried / fried deeply : word phrase; Fried is derivation; deeply is derivation.

deep-fry: compounding; both use base word (lexeme).

(Haspelmath, 2002) states "A compound is a complex lexeme that can be thought of as consisting of two or more base lexemes. In the simplest case, a compound consists of two lexemes that are joined together (called compound members)". Haspelmath also states lexeme in this theory and the number can be two or more. Haspelmath agrees with Booij that compound word should be consisted of base word. For example:

$\begin{array}{ll}\mathrm{N}+\mathrm{N} & \text { lipstick } \\ \text { Adj }+\mathrm{N} & \text { hardware } \\ \mathrm{V}+\mathrm{N} & \text { drawbridge } \\ \mathrm{N}+\mathrm{V} & \text { babysit } \\ \mathrm{N}+\text { Adj } & \text { leadfree } \\ \text { Adj }+ \text { Adj } & \text { bitter-sweet }\end{array}$

(Bauer, 2002) states that Compound word is word that consist two or more words that might be written with blank space, without blank space or hypenated that might use base word or morpheme which has singular and plural form counted as one word. Bauer gives a more complex definition than the previous theories. For example:

Girlfriend $\rightarrow$ Girl + friend, using lexeme; without blank space; apartment building $\rightarrow$ apartment + building,using lexeme; with blank space

son-in-law $\rightarrow$ son + in + law, using lexeme; hypenated; singular; sons-in-law $\rightarrow$ sons + in + law, sons is inflection; hypenated; and plural.

Thus, compound word is a word formation process that has several characters consist of two or more lexemes. It has singular and plural form, and can be written with blank, without blank or hypenated.

\section{Identifying Compound Word}

If somebody had to define what a word is, someone might first think of the word as a unit in the writing system, or known as Orthographic Word. Thus, word is an uninterrupted string of letters which is preceded by a blank space and followed either by a blank space or a punctuation mark (Bauer, 2002). This theory is strengthen by (Booij, 2012) that word can be distinguished from other linguistics such as 
phrases because word is limited to space due to orthographical convention. For example:

ex.1 Mary lives in London

There can count 4 orthographic words: there are 4 uninterrupted strings of letters, all of which are preceded by a blank space, 3 of which are also followed by a blank space, one of which is followed by a period. This count is also in accordance with our intuitive feeling of what a word is. Even without this somewhat formal and technical definition, one might want to argue that the sentence in contains 4 words. However, things are not always as straightforward. Consider the following example, and try to determine how many words there are:

ex.2 Mary's boyfriend lives in a low-cost apartment building

The result depends on a number of assumptions. If one consider apostrophies to be punctuation marks, Mary's constitutes two (orthographic) words. If not, mary's is one word. If one considers a hyphen is a punctuation mark, low-cost is two (orthographic) words, otherwise it's one (orthographic) word. The last two strings, apartment building, are easy to classify, they are two (orthographic) words, whereas girlfriend must be considered one (orthographic) word. This is the problem of defining a word.

However, there are two basic problems with this orthographic analysis. The notion of what a word is, should, after all, not depend on the fancies of individual writers or the arbitrariness of the English spelling system. The second problem with the orthographically defined word is that it may not always coincide with our intuitions. Thus, most of people would probably agree that boyfriend is one word which consists of two words, boy and friend. This is called compound. If compounds are one orthogrpahical word, they should be spelled without a blank space separating the elements that together make up the compound. Unfortunately, this is not the case. The compound apartment building, for example, has a blank space between apartment and building.

(Haspelmath, 2002) adds that "The rules for orthographic word division are to some extent simply traditional in languages with a long written history. When a language is first written down, the language-users often disagree on where to put blank spaces between words, and when a conventional spelling is agreed on, the decisions are sometimes clearly arbitrary."

So, orthographical word is helpful to identify a "word" but it can not be used to identify number of written word especially in complex written format.
With that idea, the writersmay propose that there are 3 forms of compound word. Those are:

\section{Hypenated Compound}

Hypenated Compound is the easiest compound word to be identified because it is hypened.Such as: Check-up, Check-in, Asian-American, VicePresident, Commander-in-chief, Editor-in-chief, President-elect, Mother-in-law, Dry-cleaning, Student-athlete, Self-restraint, Well-being, Singersongwriter, One-half, Runner-up, Sixteen-year-old.

\section{Closed Compound}

The two words are joined together without a hyphen or a space. Some other examples of closed form compound words include: Baseball, Windfall, Extraordinary, Metaphysical, Worldwide, Northwest, Stockbroker, Sailboat, Railway, Wildcat, Birthday.

Closed Compound is usually mistaken with Blending. Blending cuts the words then enjoined them. Blending is contracting two words together, to form a new word. For examples:

docudrama (documentary + drama), emoticon $($ emote + icon $)$, moped (motor + pedal), motel (motor + hotel), sitcom (situation + comedy), slanguage (slang + language).

\section{Open Compound}

Open Compound is compound word written as two separate words but said together as one word with its own meaning. Open Compound perhaps is most difficult to be identified. Open Compound look a lot like two independent words, but they aren't because they describe a single thing. Here are a few examples of open form compound words most people are likely familiar with:

Flight attendant, Super tanker, African American, Light year, Post office, Real estate, Truck driver, Middle class, Attorney general, High school, Vice president.

However, Non Compound is usually mistaken for Open Compound. Compound words in English can be distinguished by the tense and plural markers which cannot be attached to the first element. The writersreveal several examples. Those are:

\section{Compound Word Non Compound}

Drop kicked

Friday Nights

Dropped Kick Fridays Night 


\section{Types of Compound Word}

Compound word can be classified according to several factors. There are 2 major factors in compound word classification. Those are Lexical categories and Meaning.

\section{Lexical Categories}

Compound word is enjoined words that counted as one. Therefore, it needs a word class assignment and the word can be used properly. Experts claim that English has modifier-modified rule. Meaning, the earlier word usually describes the following word. William in (Booij, 2012) claims that condition as Right-Hand Head Rule (RHR). Williams states "In morphology, we define the head of a morphologically complex word to be the righthand member of that word." For example bottle factory, it is kind of factory, not kind of bottle. Both bottle and factory are Noun lexically but Bottle modifies the factory.

(Haspelmath, 2002) states that the first word member generally serves to modify and narrow the denotation of the second compound word, or, in other words, the compound is a hyponym of its second word. For example, lipstick is a special kind of stick (not a special kind of lip), drawbridge is a special kind of bridge and a love letter is a special kind of letter. In this sense, the second word is more important that the first. This situation refered the second word as the Head and the first as the dependant. Haspelmath adds that in English, the compound head is always the second word.

(Bauer, 2002) states that the left word modifies the right word. The term head is generally used to refer to the most important unit in complex linguistic structures. In our compounds it is the head which is modified by the other member of the compound. For example, film society is a kind of society (namely one concerned with films), a parks commissioner is a commissioner occupied with parks, to deep-fry is a verb designating a kind of frying.

Based on above theories, experts claim the same thing that in English the lexical assignment of the compound word is based on the lexical of the head word which placed in the right/second/following word. With this conclusion, writers can separate several lexical categories in compound word.

\section{Compound Noun}

Bauer in (Rahadiyanti, 2017) states that Compound Noun is the largest sub grouping compound and the most productive type of compound. Compound noun is also defined as a fixed expression which is made up of more than one word and function as a noun (McCharty in (Rahadiyanti, 2017)). Compound words can be found in newspaper, magazine, and dictionary. The noun compound can be formed from several combinations of lexical categories. The writers focus on the compound words formations of noun+ noun, adjective + noun, and verb + noun. The most productive formation is noun + noun in compound nouns (Ballard in (Rahadiyanti, 2017)). For examples:

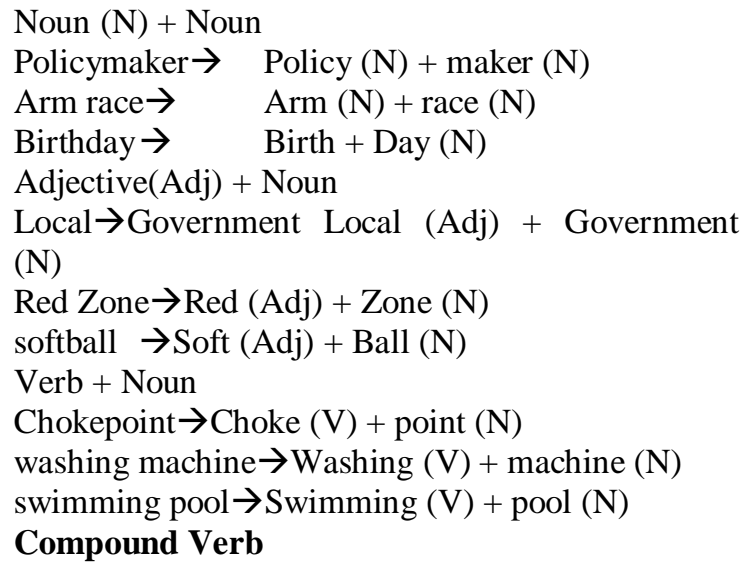

A compound verb can be composed of verb and verb, noun and verb, adjective and verb or preposition and verb. The elements can be seen as Verb + Verb, Noun + Verb, Adjective + Verb, and Preposition + Verb (Bauer in (Rahadiyanti, 2017)). For examples:

Verb + Verb

Sleepwalk $\rightarrow$ Sleep $(\mathrm{V})+$ Walk $(\mathrm{V})$

Trickle-irrigate $\rightarrow$ Trickle $(\mathrm{V})+$ Irrigate $(\mathrm{V})$

get-go $\rightarrow$ Get $(\mathrm{V})+$ Go $(\mathrm{V})$

Noun + Verb

Sky-dive $\rightarrow$ Sky $(\mathrm{N})+$ Dive $(\mathrm{V})$

babysit $\rightarrow$ Baby $(\mathrm{N})+$ Sit $(\mathrm{V})$

Childcare $\rightarrow$ Child $(\mathrm{N})+$ Care $(\mathrm{V})$

Adjective(Adj) + Verb

Fine-tune $\rightarrow$ Fine (adj) + Tune $(V)$

Double-click $\rightarrow$ Double (adj) + Click $(V)$

Dry-Cleaning $\rightarrow$ Dry (adj) + Cleaning (V)

Preposition (Prep) + Verb

Withstand $\rightarrow$ With (Prep) + stand $(\mathrm{V})$

Uphold $\rightarrow$ Up (Prep) + hold (V)

Undertake $\rightarrow$ Under (Prep) + take $(\mathrm{V})$

\section{Compound Adjective}

McCarthy in (Sari, 2013) states "Compound adjectives containing two or more words that act as a single idea to modify a noun". An adjective or a noun can be in the first element, and a participle form in the second. The elements of compound can be classified as: adjectives are Noun + Adjective, Adjective + Adjective, Adverb + Adjective and Preposition + Adjective. For examples: 


\author{
Noun $(\mathrm{N})+$ Adjective (Adj) \\ capital-intensive $\rightarrow$ Capital $(\mathrm{N})+$ intensive (adj) \\ childproof $\rightarrow$ Child $(\mathrm{N})+$ proof $(\operatorname{adj})$ \\ Adjective+ Adjective (Adj) \\ bitter-sweet $\rightarrow$ Bitter (adj) + sweet (adj) \\ red-hot $\rightarrow$ red $(\operatorname{adj})+$ hot $(\operatorname{adj})$ \\ Adverb(Adv) + Adjective \\ Counter-intuitive $\rightarrow$ counter (adv) + intuitive (adj) \\ over-qualified $\rightarrow$ Over $($ Adv $)+$ qualified $($ adj $)$ \\ Preposition (Prep) + Adjective (Adj) \\ uptight $\rightarrow$ up (prep) + tight (adj)
}

\section{Meaning / Lexical Semantic}

This study deals with the meaning of the identified compound word. It is necessary to discuss semantic for the identified compound because compound word is formed by several words that has lexical unit and individual meaning. The analysis in lexical semantics is not only for the words but also including subcategories which are affixes, phrases, and compound words (Cruse in (Rahadiyanti, 2017)).

O'Grady in (Rahadiyanti, 2017) agrees that Compound word is used to express a general meaning. Meaning, Compound word, by meaning, has a chance to be or not to be predicted from its parts. For example, White House and white house. White House is not always white because the meaning of White House is actually the official residence of the US president in Washington DC. Meanwhile, the meaning of white house is a house which is painted with white color. New example, Greenhouse and green house. The word greenhouse has a meaning of a glass enclosed garden. Therefore, the meaning of greenhouse is not a kind of house. Meanwhile, green house means a house which is painted with green color.

Many compound words are idiomatic and create an entirely different (Fromkin, et.al in (Rahadiyanti, 2017). For example, sugar daddy. The meaning of sugar daddy is not a father who brings or sells sugar. Sugar daddy is a rich older man who lavishes gift on a young woman in return for her company. Another example is road hog. Road hog does not express a kind of hog, but it is a motorist who drives recklessly or inconsiderately.

Morphologists agree to split the type of compound word based on the meaning. Those are:

\section{Endocentric}

Katamba in (Rumiyati, 2015) said that, most compound in English are endocentric, they have a head. In such compound, normally the head element appears as the right-handmost constituent of the word. Semantically an endocentric compound indicates a sub-grouping within the class of entities that the head denotes. For example: a schoolboy is a kind of a boy and a bedroom is a kind of room.

O'Grady in (Rahadiyanti, 2017) states Endocentric compound can be identified literally by its head. In this case, The Right-Hand Head Rule (RHR Rule). For example, steamboat. Steamboat is a kind of boat. Steamboat has a meaning of a boat powered by steam. The second example is airplane. Airplane is a kind of plane which travels through the air. Then, the last example is bath towel. Bath towel is a towel to be used after bathing.

(Bauer, 2002) defines the Endocentric Compound as compound word that has semantic head inside the compound (RHR Rule). For example: laser printer is a kind of printer, a book cover is a kind of cover, a letter head is the head of a letter.

Thus, Endocentric Compound is compound word which meaning follows the semantic meaning of the head.

\section{Exocentric}

Exocentric compound is a compound which meaning does not derived semantically from its parts, neither the modifier nor the head (O'Grady in (Rahadiyanti, 2017)). For example, red head. Red head is not a type of head. It is a person who has red hair. Another example is redneck. Redneck is not a kind of neck, but it is a working-class white person from southern US. Based on the previous examples, the meaning of compound word cannot be identified from its parts. The pluralization in exocentric compound is different from endocentric compound. Exocentric compound permits the plural suffix $-\mathrm{s}$. The examples of pluralization in exocentric compound are tooths, foots, mans, and leafs.

Exocentric compounds or bahuvrihi compounds are headless compounds which do not contain an element that function as the semantic head which is modified by the nonhead element (Rumiyati, 2015). There is no modifier-modified relationshop in exocentric compounds. For examples; a blue-nose is not a nose at all but a purplish variety of potato grown in Nova Scotian, and white-collar is neither a kind of a collar nor a white thing, but the meaning is something which is related with a worker.

(Bauer, 2002) defines the Exocentric Compound as Compound Word that has semantic outside of the compound. Exocentric is also known as Bahuvrihi Compound which originated from ancient sanskirt. For example; Airhead has no relations to Air (Force of Nature) nor head (part of body), but it means 
person with slow response or stupid as if there is only air in the head.

Writers conclude that Exocentric Compounds is compound word that generates new meaning which has no semantic meaning from its parts.

\section{Copulative, Coordinative and Appositional Compound}

Copulative Compound is a compound that has no semantic head and the relation between the constituent is a relation of coordination (Booij, 2012). Copulative is known as Dvanda Compound because it is commonly found in ancient sanskirt. This Compound works as dual expression, therefore, it is counted as plural word. For example:

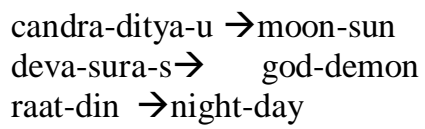

Booij gives examples of copulative that are found in european language: German Österreich-Ungarn Austria and Hungary; Fürstbischof $\rightarrow$ prince and bishop; Dutch; rood-wit-blauw $\rightarrow$ red-white-blue; English; blue-green, washer-dryer.

Copulative theory is strenghtened by (Bauer, 2002). Bauer presents an example: A geologist-astronomer is one person that is an astronomer and at the same time a geologist.

However, Booij states that copulative compounds are different from dvanda compounds it is counted as singular. A Fürstbischof is a person who is simultaneously a prince and a bishop, and this word does not refer to a combination of persons. Therefore, such compounds are sometimes classified as appositive compounds.

On the other hand, (Haspelmath, 2002) defines such theories as Appositional Compounds. A non-head compound that is rarely found in european languages but common in spanish.

poeta-pintor $\rightarrow$ poet who is also a painter' actor-bailarin $\rightarrow$ actor who is also a dancer' compositor-director $\rightarrow$ composer who is also a director

(Haspelmath, 2002) also states that there is a compound with more than one head. Haspelmath calls it as Coordinative Compound. In coordinative compounds, both members are on an equal footing, and they can be paraphrased with 'and', so they are called coordinative compounds. Some examples from Korean

elun-ai $\rightarrow$ 'adult and child'(elun 'adult' + ai 'child'); ma-so $\rightarrow$ 'horses and cattle'(ma 'horse' + so 'cow') non-path $\rightarrow$ 'farm'(non 'rice field' + path 'dry field') o-nwui $\rightarrow$ 'brother and sister'(o 'brother' + nwui 'sister')

son-pal $\rightarrow$ 'hand and foot' (son 'hand' + pal 'foot')

With explanation above, writers conclude that Copulative, Coordinative and Appositional Compound are compound with balance head. There is no modifier-modified relationship.The differences are Copulative and Coordinative is counted as plural while appositional is counted as singular.

\section{Lyrics}

Lyrics or song lyrics are words that comes from either experience or imagination. Based on Ramphur in (Amanda \& Sutrisno, 2017), lyrics are words that specifically made for music. This theory explicitly associates lyrics for musical performance.

Lyric is shown as artistic license which expressed feeling (Hornby in (Christianto, 2018)). Williams in (Yastanti, 2018) states "The lyrics or personal poem is often considered as expressive, and the "expressive" lyric posits the self as the primary organizing principle of the work. Both definitions above agree lyrics are personal expression, but every single art in life can be considered as expression but it does not mean understandable because the attributes and the elements in lyrics can be abstract.

Morphologically, compound word is one of the word formation process. Yule in (Rahayu, 2016) classifies word formation process into 10 such as, coinage, borrowing, compounding, blending, backformation, conversion, acronyms, derivation, and multiple-processes. This research discusses compounding as a part of word-formation processes. This topic is chosen because compound words has specific characteristics in their morphological aspects.

Mastering the compound words formation in the Time of the Oath Album and the dominant category of the compound words found in it can give significance positive to enrich teachers and language learners relate to glossary. Thus it alerts language users the tendency of word formation results in compound words.

\section{RESEARCH METHODOLOGY}

This research uses descriptive qualitative method. The corpus data was taken from darklyrics.com. The data Helloween's Album The Time of the Oath 
Japanese version identified were taken on December, 20th 2019. First, writers identify the data based on presented theories. Second, writers classify and analyze the data into the correct classification and meaning using RHR model. Final act, writers determine the dominant category shown in the table.

The first thing to learn compound word is Identification. One must be able to identify it first. Compound word can not be identified in oral/spoken form, but it can be identified in written form. Identifying compound word begins with learning concept of word.

The identified data will be analyzed to determine the classification. Writers will analyze the lexical assignment then analyze the meaning. Writers use (Merriam-Webster) Dictionary and (oxfordlearnersdictionaries). To decide lexical category of each word and writers use Right-Hand Head Rule (RHR) to analyze the Lexical.

The last step is to see the dominant category of word formation. The dominance of word formation is easier when applied in a table so that the percentage and tendency of word formation can be known.

\section{FINDING AND RESULTS}

\section{Identification and Classification}

There are found 22 compound words. The corpus data are shown below.
1. Headless
2. cold hand
3. steel tormentor
4. Muscular contraction
5. Nightride
6. taillights
7. steel bride
8. Forever and one
9. Neverland
10. Cold-hearted
11. Holy Fire
12. Somewhere
13. Night Generation
14. Motherland
15. Sunlit
16. Faceless
17. Understand
18. Someday
19. Winter Night
20. Overcoming
21. Rubbersex
22.Somebody

The 22 identified compound words are the classified. The classification to the type of compound words are important to know the detail of types and word formation.

\section{Data Analysis}

1. Headless

Headless $\quad:$ Head + Less

According to dictionary, Head is a Noun: Part of body ; intelectuality ; person;leader. Less is Adj: used with uncountable nouns to mean "a smaller amount of". By using RHR rule, Headless is an adjective. it means unorganized; no direction. Therefore, Headless is an endocentric compound, because meaning is still connected semantically.

\section{Cold Hand}

Cold Hand $\quad$ : Cold + Hand

Cold is Adj: low temperature;lack of human emotion;gloomy; unfriendly. Hand is Noun: the part of the body at the end of the arm, including the fingers and thumb / Help / person or method of extension / something plays in a particular. By using RHR Rule, Cold Hand is a Noun. It means act or method with lack of human feeling. Therefore, Cold Hand is an Exocentric Compound because the meaning is outside the semantic meaning.

\section{Steel Tormentor}

\section{Steel Tormentor : Steel + Tormentor}

Steel is Noun: kind of iron; quality that resembles steel in hardness in physical or spirit. Steel can be a Adj: resembling steel. Tormentor is Noun: a person who causes somebody to suffer. Writers conclude Steel works as an Adjective. By using RHR rule, Steel Tormentor is a Noun. It means $a$ person who causes suffering with Hardness in him. Therefore, Steel Tormentor is a Endocentric Compound because the meaning is inside the semantic meaning.

\section{Muscular Contraction}

Muscular Contraction : $\quad$ Muscular + Contraction

Muscular is Adj: connected with the muscles; having large strong muscles. Contraction is Noun: the shortening and thickening of a functioning muscle or muscle fiber. By using RHR rule, Muscular Contraction is a Noun. It means something that is happening with muscle. Therefore, Muscular Contraction is an Endocentric 
Compound because the meaning is inside the semantic meaning.

\section{Nightride}

Nightride

$$
\text { : Night + Ride }
$$

Night is Noun: the time between one day and the next when it is dark, when people usually sleep. Ride is Verb : to sit on a horse, etc. and control it as it moves; to travel in or on a conveyance. Ride can also be a Noun: a short journey in a vehicle, on a bicycle, etc; to a place you want to get to. Writers conclude Ride works as Noun. By using RHR rule, Nightride is a Verb. It means riding in the night time. Therefore, Nightride is a Endocentric Compound because the meaning is inside the semantic meaning.

\section{Taillights}

Taillights $\quad:$ Tail + Lights

Tail is Noun: the rear end or a process or prolongation of the rear end of the body of an animal; omething resembling an animal's tail in shape or position. Tail can also be a Verb: to follow for purposes of surveillance; to connect end to end. Light is Noun: that makes it possible to see things; something that makes vision possible; a particular illumination; something that enlightens or informs. By using RHR rule, Taillights is a Noun. It means $a$ tail that has lights. Therefore, Taillights is an Endocentric Compound because the meaning is inside the semantic meaning.

\section{Steel Bride}

\section{Steel Bride $\quad$ : Steel + Bride}

Steel is Noun: kind of iron; quality that resembles steel in hardness in physical or spirit. Steel can be a Adj: resembling steel. Bride is Noun: a woman on her wedding day, or just before or just after it; a woman just married or about to be married. Writers conclude Steel works as an Adjective. By using RHR rule, Steel Bride is a Noun. It means Tough Intimate partner. Therefore, Steel Bride is an Endocentric Compound because the meaning is inside the semantic meaning.

\section{Forever and One}

Forever and One : Forever + And + One

Forever is Adv: for a limitless time; at all times; continually; particular situation or state will always exist; very long time. And is Conjunction. One is Adj: being a single unit or thing. By using RHR rule, Forever and One is an Adjective. It means Everlasting for a single thing. Therefore,
Forever and One is Endocentric Compound because the meaning is inside the semantic meaning.

\section{Neverland}

Neverland $\quad:$ Never + land

Never is Adv: not in any degree; not under any condition. Land is Noun: the surface of the earth that is not sea; realm; domain. Land can also be a Verb: to set down after conveying; to bring to a specified condition. Writers choose the Noun version of Land in this analysis. By using RHR Rule, Neverland is a Noun. It means A fictional place in Peterpan story. Therefore, Neverland is Exocentric Compund because the meaning is outside the semantic meaning.

\section{Cold-Hearted}

\section{Cold-Hearted $\quad$ : Cold + Hearted}

Cold is Adj: low temperature; lack of human emotion; gloomy; unfriendly. Hearted is Adj:having the type of character or personality mentioned; having a heart especially of a specified kind usually used in combination. By using RHR rule, Cold-hearted is an Adjective. It means Unfriendly personality. Therefore, Cold-hearted is Endocentric Compound because the meaning is inside the semantic meaning.

\section{Holy Fire}

$$
\text { Holy Fire } \quad: \text { Holy }+ \text { Fire }
$$

Holy is Adj: exalted or worthy of complete devotion as one perfect in goodness and righteousness; good in a moral and religious way. Fire is Noun: the flames, light and heat, and often smoke, that are produced when something burns; a destructive burning; the phenomenon of combustion manifested in light, flame, and heat. By using RHR rule, Holy Fire is a Noun. It means Sacred or exalted fire. Therefore, Holy Fire is Endocentric Compound because the meaning is inside the semantic meaning.

\section{Somewhere}

Somewhere : Some + where

Some is Adj: being an unknown, undetermined, or unspecified unit or thing. Where can be Adv: at, in, or to what place. Where can be a Noun: place; location. Writers conclude Where as Noun. By using RHR rule, Somewhere is a Noun. It means undetermined place. Therefore, Somewhere is Endocentric Compound because the meaning is inside the semantic meaning. 


\section{Night Generation}

Night Generation : Night + Generation

Night is Noun: the time between one day and the next when it is dark, when people usually sleep. Generation is Noun: a group of individuals having contemporaneously a status (such as that of students in a school) which each one holds only for a limited period; all the people who were born at about the same time; a group of people of similar age involved in a particular activity. By using RHR rule, Night Generation is a Noun. It means a period of time when a group of individuals do vertain acitivity in night time. Therefore, Night Generation is Endocentric Compound because the meaning is inside the semantic meaning.

\section{Motherland}

Motherland $\quad$ : Mother + Land

Mother is Noun: a female parent; source; origin. Land is Noun: the surface of the earth that is not sea; realm; domain. Land can also be a Verb: to set down after conveying; to bring to a specified condition. Writers conclude Land works as Noun. By using RHR rule, Motherland is a Noun. It means a place of origin; hometown. Therefore, Motherland is Endocentric Compound because the meaning is inside the semantic meaning.

\section{Sunlit}

Sunlit

$$
\text { : Sun }+ \text { Lit }
$$

Sun is Noun: the star that shines in the sky during the day and gives the earth heat and light. Lit is Noun: past tense and past participle of light. By using RHR rule, sunlit is a noun. It means light from the sun. Therefore, sunlit is Endocentric Compound because the meaning is inside the semantic meaning.

\section{Faceless}

Faceless : Face + less

Face is Noun: the front part of the head that in humans extends from the forehead to the chin and includes the mouth, nose, cheeks, and eyes; outward appearance; assurance; confidence; dignity; prestige. Less is Adj: used with uncountable nouns to mean "a smaller amount of". By using RHR rule, Faceless is an Adjective. It means things that has no appearance in the head. Therefore, Faceless is Endocentric Compound because the meaning is inside the semantic meaning.

\section{Understand}

Understand $\quad$ : Under + Stand

Under is Adj: in, to or through a position that is below something. Stand is Verb: to be on your feet; to be in a vertical position; to take up or maintain a specified position or posture. By using RHR rule, Understand is a Verb. It means to grasp the meaning of; to know or realize the meaning of words, a language, what somebody says, and so on. Therefore, Understand is Exocentric Compound because the meaning is outside the semantic meaning.

18. Someday

Someday $\quad$ : Some + Day

Some is Adj: being an unknown, undetermined, or unspecified unit or thing. Where can be Adv: at, in, or to what place. Day is Noun: the time of light between one night and the next; the time between when it becomes light in the morning and when it becomes dark in the evening; a particular period of time or history. By using RHR rule, Someday is a Noun. It means undetermined period of time. Therefore, Someday is Endocentric Compound because the meaning is inside the semantic meaning.

\section{Winter night}

\section{Winter Night $\quad$ : Winter + Night}

Winter is Noun: the coldest season of the year, between autumn/fall and spring. Night is Noun: the time between one day and the next when it is dark, when people usually sleep. By using RHR rule, Winter Night is a Noun. It means a night in winter. Therefore, Winter Night is Endocentric Compound because the meaning is inside the semantic meaning.

\section{Overcoming}

Overcoming : Over + Coming

Over is Adverb: downwards and away from a vertical position; from one side to another side; so as to cover somebody/something completely; above; more. Over can be a Prep: used as a function word to indicate motion or situation in a position higher than or above another; used as a function word to indicate the possession of authority, power, or jurisdiction in regard to some thing or person; used as a function word to indicate superiority, advantage, or preference. Coming is derived from lexeme Come, which is a Verb: to move to or towards a person or place; to arrive at or reach a place. Come convertsto Noun into Coming through Gerund rules. Coming as Noun: an 
act or instance of arriving. But Coming as Verb has same meaning with Come. Writers conclude that Over works as Adv and Coming will be used in this analysis. By using RHR rule, Overcoming is Verb. It means Arrive after to succeed in dealing with or controlling a problem that has been preventing you from achieving something. Therefore, Overcoming is Exocentric Compound because the meaning is outside the semantic meaning.

\section{Rubbersex}

Rubbersex : Rubber + Sex

Rubber is Noun: an instrument or object (such as a rubber eraser) used in rubbing, polishing, scraping, or cleaning; natural or synthetic rubber modified by chemical treatment to increase its useful properties (such as toughness and resistance to wear) and used especially in tires, electrical insulation, and waterproof materials. Sex is Noun: either of the two major forms of individuals that occur in many species and that are distinguished respectively as female or male especially on the basis of their reproductive organs and structures; the state of being male or female; physical activity between two people in which they touch each other's sexual organs, and which may include sexual intercourse. By using RHR rule, Rubbersex is Noun. It means Sex Toys. Therefore, Rubbersex is Exocentric Compound because the meaning is outside the semantic meaning.

\section{Somebody}

Somebody $\quad$ : Some + Body

Some is Adj: being an unknown, undetermined, or unspecified unit or thing. Where can be Adv: at, in, or to what place. Body is Noun: the main part of a plant or animal body especially as distinguished from limbs and head; a human being. By using RHR rule, Somebody is Noun. It means unspecified person. Therefore, Somebody is Endocentric Compound because the meaning is inside the semantic meaning.

The analzyed data will be put into table to be organized as shown below:

\begin{tabular}{llll}
\hline \multicolumn{1}{c}{ Data } & Formation & $\begin{array}{c}\text { Lexical } \\
\text { Head }\end{array}$ & Meaning \\
\hline Headless & $\mathrm{N}+\mathrm{Adj}$ & $\mathrm{Adj}$ & Endocentric \\
\hline Cold Hand & $\mathrm{Adj}+\mathrm{N}$ & $\mathrm{N}$ & Endocentric \\
\hline $\begin{array}{l}\text { Steel } \\
\text { Tormentor }\end{array}$ & $\mathrm{Adj}+\mathrm{N}$ & $\mathrm{N}$ & Endocentric \\
\hline $\begin{array}{l}\text { Muscular } \\
\text { Contraction }\end{array}$ & $\mathrm{N}+\mathrm{N}$ & $\mathrm{N}$ & Endocentric \\
\hline Nightride & $\mathrm{N}+\mathrm{N}$ & $\mathrm{N}$ & Endocentric \\
\hline Taillights & $\mathrm{N}+\mathrm{N}$ & $\mathrm{N}$ & Endocentric \\
\hline
\end{tabular}

\begin{tabular}{llll}
\hline Steel Bride & Adj $+\mathrm{N}$ & $\mathrm{N}$ & Endocentric \\
\hline $\begin{array}{l}\text { Forever and } \\
\text { One }\end{array}$ & $\begin{array}{l}\mathrm{Adv}+ \\
\mathrm{Conj}+\mathrm{Adj}\end{array}$ & $\mathrm{Adj}$ & Endocentric \\
\hline Neverland & $\mathrm{Adv}+\mathrm{N}$ & $\mathrm{N}$ & Exocentric \\
\hline $\begin{array}{l}\text { Cold- } \\
\text { Hearted }\end{array}$ & $\mathrm{Adj}+\mathrm{Adj}$ & $\mathrm{Adj}$ & Endocentric \\
\hline Holy Fire & $\mathrm{Adj}+\mathrm{N}$ & $\mathrm{N}$ & Endocentric \\
\hline Somewhere & $\mathrm{Adj}+\mathrm{N}$ & $\mathrm{N}$ & Endocentric \\
\hline $\begin{array}{l}\text { Night } \\
\text { Generation }\end{array}$ & $\mathrm{N}+\mathrm{N}$ & $\mathrm{N}$ & Endocentric \\
\hline Motherland & $\mathrm{N}+\mathrm{N}$ & $\mathrm{N}$ & Endocentric \\
\hline Sunlit & $\mathrm{N}+\mathrm{N}$ & $\mathrm{N}$ & Endocentric \\
\hline Faceless & $\mathrm{N}+\mathrm{Adj}$ & $\mathrm{Adj}$ & Endocentric \\
\hline Understand & $\mathrm{Adj}+\mathrm{V}$ & $\mathrm{V}$ & Exocentric \\
\hline Someday & $\mathrm{Adj}+\mathrm{N}$ & $\mathrm{N}$ & Endocentric \\
\hline Winter Night & $\mathrm{N}+\mathrm{N}$ & $\mathrm{N}$ & Endocentric \\
\hline Overcoming & $\mathrm{Adv}+\mathrm{V}$ & $\mathrm{V}$ & Exocentric \\
\hline Rubbersex & $\mathrm{N}+\mathrm{N}$ & $\mathrm{N}$ & Exocentric \\
\hline Somebody & $\mathrm{Adj}+\mathrm{N}$ & $\mathrm{N}$ & Endocentric \\
\hline
\end{tabular}

Based on the table, of 22 data gathered, writers may conclude that the most dominant Formation: Noun + Noun formation is most frequent. It appears 8 times of $22(36.3 \%)$. On other hand, Adj + Noun Appears 7 times of $22(31,8 \%)$. The most dominant Lexical head is Noun. It appears 16 times of 22 (72.7 \%). Endocentric Compound appears 18 times of $22(81.8 \%)$ while Exocentric only appears 4 times of $22(18.1 \%)$.

\section{CONCLUSION}

There are two findings that the writers found in the analysis. Firstly is the formation of compound word. Secondly is the meaning of compound word.

Related to the formation of compound words, compound nouns, compound adjectives, and compound verbs are formed dominantly and productive respectively. The formation is related to the lexical categories.

Related to the meaning of compound word, there are endocentric compound and exocentric compound.

This process of word formation needs to be mastered by the teachers and the learners of English, as different forming of words conveys different meaning.

\section{REFERENCES}

Amanda, \& Sutrisno. (2017). A figurative language analysis of song lyric "Mirrors" by Justin Timberlake. JELL-STIBA IEC, Vol 2, No 2, September 2017. 
Bauer, L. (2002). Word-Formation in English Draft Version. Cambridge University Press.

Booij, G. (2012). The Grammar of Words. Oxford University Press.

Ceylan, H. (2017). Different Perspectives on the Origin of Language and the Evidences from the Field of Language Acquisition. International Journal of Language and Linguistics Vol. 4, No. 3.

Christianto, D. (2018). Syntactical Analysis on sentence patterns on John Denver's Song lyrics. Bachelor Thesis of Sanata Dharma University.

Eunhee Lee, . M.-J. (2015). An Introduction to Korean Linguistics. New York: Routledge.

Haspelmath, M. (2002). Understanding Morphology. Oxford University Press.

Merriam-Webster. (n.d.). https://www.merriamwebster.com. Retrieved December 2019, from https://www.merriam-webster.com

oxfordlearnersdictionaries. (n.d.). https://www.oxfordlearnersdictionaries.co $m$. Retrieved December 2019, from https://www.oxfordlearnersdictionaries.co m
Rahadiyanti. (2017). Compound Words found in Political articles. Strategic Review Magazine.

Rahayu, e. a. (2016). A Morphological Analysis on English Compound Words in Five Articles of BBC New. Jember University : Artikel Ilmiah Mahasiswa 2016, .

Rumiyati, A. (2015). A MORPHOLOGICAL ANALYSIS OF COMPOUND WORDS USED IN NOVEL “THE SINGLE GIRL'S TO-DO LIST” BY LINDSEY KELK.

Surakarta: Muhammadiyah University of Surakarta.

Sari, R. (2013). Compounding in Information Technology terms: A Morphological Study. Universitas Padjajaran Journal bahasa \& sastra, Vol. 13, No.1.

Yastanti, e. a. (2018). Figurative language in song lyrics of Linkin Park2018. BSI Progressive Journal Vol XIII, No 2. 